which it was then supposed erroneously to be a mere offshoot. His translation of the Jain Sutras appeared in the Sacred Books of the East edited by Max Müller; and in 1879 he published an edition of the Kalpa Sutra, the recognized manual of the community, with an English introduction. He also edited three important Prakrit texts, which appeared at intervals between 1883 and 1923 in the "Bibliotheca Indica". He was the first to give Apabhramsa texts, which mark the transition from Prakrit to modern languages. His collection of Jain tales (1930) is in general use as a text-book. In 1913 Jacobi revisited India to lecture before the University of Calcutta on Indian rhetoric. His reception by Jain pandits on that occasion not only threw open to him material usually not accessible to foreigners, but also manifested the high esteem in which he was held in the Jain community.

Jacobi's contributions to Sanskrit learning were no less important and covered a wide field, including the study of the Indian doctrine of poetics, the Ramayana and Mahabharata, to which he is the most authoritative guide, and Indian chronology, a subject in which his studies in the Indian Antiquary of 1888 and Epigraphica Indica of 1892, with further tables published two years later, are the fundamental calculations for all later work. In comparative philology he developed important theories as regards the characteristics of certain Asiatic languages as compared with the Indo-European group. He was also an authority of the first rank on Indian philosophy, an important study being "The Origin of Buddhism from the Sankhya Yoga" (1896).

Jacobi's eminence as an Oriental scholar was recognized on the occasion of his seventy-fifth birthday, on February 11, 1925, when he was the recipient of a volume of contributions from forty-seven prominent Orientalists, among whom Britain was represented by Sir George Grierson, Dr. F. W. Thomas and Prof. R. L. Turner.

\section{Mr. A. B. Brewster}

WE regret to record the death of Mr. A. B. Brewster, formerly Governor's Commissioner of Colo, North and East Fiji, which took place at Bath on October 13 at the age of eighty-two years.

Adolph Brewster Brewster was born in Melbourne and educated in England. On his return to Australia, with his father in 1870 he took up a land grant in Fiji from the Polynesian Company, which had acquired a large concession of land around Suva from King Cakobau (Thakombau). On the failure of his venture in cotton and sugar planting, he entered the Fijian Civil Service in 1884, and served until his retirement in 1910.

Later, as Governor's Commissioner of the mountain provinces of Vitilevu, Brewster acquired an intimate and sympathetic knowledge of the wild mountaineers and their customs, of which he gave a vivid and detailed account in his book "The Hill Tribes of Fiji". $\mathrm{He}$ was also the author of "King of the Cannibal Islands", which appeared recently. It was through a letter written by him to The Times that the war club presented to Queen Victoria by King Cakobau was returned to Fiji in 1932 to serve as the mace of the Legislative Council. A further service to Fijian studies, for which posterity will be grateful, was the compilation of a manuscript record of a native version of the organization of Fijian society, which was undertaken at his request by a native clerk, preserving a tradition which otherwise would have died out.

\section{Mrs. F. L1. Griffith}

WE regret to record the death of Mrs. Griffith, widow of the late Francis Ll. Griffith, professor of Egyptology in the University of Oxford, which took place at Oxford on October $2 \mathrm{I}$ at the age of sixty-four years. Mrs. Griffith became interested in Egyptology after a visit to Egypt in 1906, and studied under Prof. Griffith, whom she married in 1909. From that time onward she was closely associated with her husband in his archæological and linguistic studies, and accompanied him on his expeditions of archæo. logical investigation in Egypt, Nubia and the Sudan in 1910-13, 1923, 1929 and 1930. After his death in 1934, she devoted herself to superintending and her. self working at the numerous undertakings which he had planned, but had left uncompleted. She had already published two volumes of the "Demotic Graffiti in the Dodecaschœnus", of which the seventy plates were prepared by herself. She also actively. supported by the expenditure of time and money the further excavations at Firka and Kawa in the Sudan in connexion with the Oxford Excavations in Nubia, a trust which had been founded by her husband in 1910.

Mr. Herbert William England, who died at the age of fifty-five years on October 30, had for nearly forty years been in charge of the departmental library of the Zoological Department of the British Museum (Natural History). Mr. England possessed an unrivalled knowledge of zoological literature and will be greatly missed by the many zoologists at whose disposal his knowledge and his ability in tracing obscure references were freely placed. He entered the Museum service as a boy attendant in February 1898 and attained the rank of higher grade technical assistant in 1932. Among his colleagues his kindly, helpful and generous character was well known, and the high regard in which he was held in the Museum is illustrated by the fact that he was one of the three recipients among the Museum staff of the King's Coronation Medal.

WE regret to announce the following deaths :

Sir Joseph Isherwood, Bt., who devised the longitudinal framing method for the constmuction of cargo boats and tankers, on October 24, aged sixty-seven years.

Prof. J. B. Senderens, correspondant of the Section of Chemistry of the Paris Academy of Sciences and honorary fellow of the Chemical Society, aged eighty one years. 